\title{
PENGARUH INTERVAL PENGENDALIAN GULMA DAN APLIKASI HERBISIDA TERHADAP PERTUMBUHAN GULMA DAN TANAMAN KARET TBM
}

\author{
The Effect of Weed Control Intervals and Herbicide Application to Weed \\ and Immature Rubber Plant Growth \\ ZULKIPLI $^{1 *)}$, YAKUP $^{2)}$, Erizal SODIKIN ${ }^{2)}$ dan Yernelis SYAWAL ${ }^{2)}$ \\ 1) Sekolah Menengah Kejuruan Pertanian Pembangunan Negeri Sembawa \\ J1. Raya Palembang - Pangkalan Balai KM 29 \\ Sembawa Banyuasin Sumatera Selatan \\ Email: zulkipli658@gmail.com \\ ${ }^{21}$ Program Pascasarjana Universitas Sriwijaya, \\ J1. Padang Selasa No. 524 Palembang Sumatera Selatan
}

Diterima : 22 Juli 2016 / Direvisi : 23 September 2016 / Disetujui : 25 Oktober 2016

\begin{abstract}
The ineffective weed control method results in other weeds dynamics that are more difficult to be controlled and subsequently produce adverse consequences on plant growth. The weeds existence on immature rubber plantation results in delay of tapping maturity of about 2 to 3 years. The research objective was to study the growth of weed and rubber due to several weed control intervals and herbicides application at young rubber plantation. The study location was on farmer plantation at Talang Kemang Village, Banyuasin District. It was conducted from December 2013 to June 2014. This research used a Split Plot Design with weed control intervals as the main plot consisting of one month, two months and six months, whereas herbicides application was used as the subplot consisting of glyphoshate, paraquat, glyphosate + methyl metsulfuron, paraquat + methyl metsulfuron, mowing and control treatments respectively with three replications. Research finding, in the pre treatment wide leaf weed growth was more dominant (SDR 52.76\%) than narrow leaf weed (SDR 47.24\%). Dry weight and weed covered were less, in short interval control. Dry weight on each treatment was significantly different on June and December 2013. Dry weight and covered of weed in glyphosate + methyl metsulfuron treatment was lowest and the highest was on mowing and control treatment. Dry weight and covered was obviously different between glyphosate + methyl metsulfuron treatment
\end{abstract}

with mowing and control treatment. The mixed herbicides treatment paraquat + methyl metsulfuron resulted in better rubber girth $(17.1 \mathrm{~cm})$ than that of glyphosate + methyl metsulfuron treatments $(16.9 \mathrm{~cm})$ The girth growth of rubber plant was very influenced by dry weight of with and the ditermination coefficient value was $R^{2}=0.828$. It could be concluded that herbicide glyphosate + metyl metsulfuron treatment was more effective to decrease the growth of weed and girth growth of rubber plant was very influenced dry weight of weed and the had negative relationship.

Keywords: Herbicide application; growth of weed; rubber

Abstrak
Metode pengendalian gulma yang
tidak efektif akan menyebabkan dinamika
gulma ke jenis yang lebih sulit dikendalikan
dan tertundanya matang sadap 2-3 tahun.
Penelitian ini untuk mengkaji pertumbuhan
gulma dan tanaman karet akibat pengaruh
berbagai interval pengendalian dan aplikasi
herbisida pada kebun karet TBM. Penelitian
dilaksanakan dari Januari 2013 sampai
Juni 2014. Rancangan penelitian disain
Split Plot, petak utama adalah perlakuan
interval pengendalian gulma dan perlakuan
herbisida sebagai anak petak dengan
ulangan 3 kali. Hasi1 pen elitian
menunjukkan bahwa pertumbuhan gulma
daun lebar lebih dominan (SDR 52,76\%)


dari gulma sempit (SDR 47,24\%) di awal penelitian (pra perlakuan). Bobot kering dan penutupan gulma lebih rendah, pada interval pengendalian lebih singkat. Bobot kering gulma antar petak perlakuan berbeda nyata pada Juni dan Desember 2013 sedangkan penutupan gulma pada bulan Desember 2013. Bobot kering dan penutupan gulma terendah pada perlakuan glifosat + metil metsulfuron yang tertinggi pada perlakuan ditebas dan kontrol. Bobot kering dan pentupan gulma selalu berbeda nyata antara perlakuan glifosat + metil metsulfuron dengan perlakuan ditebas dan kontrol. Perlakuan herbisida campuran parakuat + metil metsulfuron menghasilkan pertumbuhan lilit batang karet lebih baik $(17,9 \mathrm{~cm})$ dibanding perlakuan glifosat + metil metsulfuron $(16,9 \mathrm{~cm})$. Pertumbuhan lilit batang tanaman karet sangat dipengaruhi oleh bobot kering gulma dengan nilai koefisien diterminasi $R^{2}=0,82$. Dapat disimpulkan bahwa perlakuan herbisida glifosat + metil metsulfuron lebih efektif menekan pertumbuhan gulma dan pertumbuhan lilit batang karet sangat dipengaruhi oleh bobot kering gulma yang membentuk pola hubungan pertumbuhan negatif.

Kata kunci: Aplikasi herbisida; pertumbuhan gulma; karet

\section{PENDAHULUAN}

Menurut Damanik et al (2010) dan Saleh (2011) sejak dekade 1980 hingga saat ini masalah di perkebunan karet, terutama kebun rakyat adalah rendahnya produktivitas, rata-rata hanya sekitar 1,106 $\mathrm{Kg} / \mathrm{KK} / \mathrm{Ha} /$ tahun dibandingkan Thailand yang telah mencapai 1,705 $\mathrm{Kg} / \mathrm{KK} / \mathrm{Ha} /$ tahun pada tahun 2011. Supriadi (2011) dan Syarifah et al (2014) menyatakan bahwa produktivitas kebun karet sangat ditentukan oleh perawatan kebun (60\%). Kegiatan pengendalian gulma merupakan kegiatan perawatan kebun yang dominan pada kebun karet masa tanaman belum menghasilkan (TBM) yang memerlukan biaya hingga sebesar $70 \%$ dari total biaya perawatan kebun. Gulma yang merupakan tumbuhan liar pada lahan budidaya yang tidak dikehendaki keberadaannya dapat menimbulkan kerugian secara perlahan selama gulma tersebut berinteraksi dengan tanaman sehingga harus dikendalikan (Faisal, et al., 2013; Isda et al., 2013). Kerugian yang ditimbulkan gulma di kebun karet antara lain terjadi persaingan tanaman dalam memanfaatkan mineral hidrologi dan sarana tumbuh seperti air, unsur hara, cahaya matahari serta ruang untuk tumbuh, menunda matang sadap 2-3 tahun, menurunkan efisiensi pemupukan dan menyebabkan kebakaran (Supawan \& Hariyadi, 2014; Suryaningtyas, 2014). Gulma juga menimbulkan kerugian melalui proses alelopati yaitu proses penekanan pertumbuhan akibat senyawa kimia (aleokimia) yang dikeluarkan oleh gulma (Sembodo, 2010).

Pada kebun karet masa TBM gulma yang berasosiasi dengan tanaman terdiri dari berbagai jenis gulma baik gulma dari golongan rumput, daun lebar semusim atau tahunan. Pada lahan yang baru dibuka atau kebun karet masa TBM umumnya banyak ditumbuhi jenis gulma rumput seperti Digitaria adscendets (H.B.K.) Hern., jenis gulma teki seperti Cyperus irria, jenis gulma herba seperti Borreria latifolia, Ageratum coneyzoides, Mimosa invisa dan jenis gulma semak Euphatorium odoratum dan Melastoma affinne (Linn.) (Budi et al., 2008; Moenandir, 2010; Sari \& Rahayu, 2013). Menurut Wibowo dan Nazif (2007) dan Girsang (2012) untuk mengendalikan gulma yang beragam pada kebun karet dapat menggunakan herbisida yang berspektrum tinggi, non selektif seperti glifosat. Untuk meningkatkan daya berantas herbisida dapat juga diaplikasikan herbisida campuran sistemik + sistemik atau kontak + sitemik. Herbisida sistemik hanya mampu menekan atau membunuh gulma tertentu dan tidak mempengaruhi tanaman lain disekitar gulma (Fatonah, Asih, Mulyanti, \& Iriani, 2013). Sedangkan pada herbisida kontak pengendalian gulma dilakukan dengan cara mematikan bagian dari gulma yang terkena atau terkontak langsung dengan herbisida (Krisno, 2016). Selanjutnya Faiz (2006) melaporkan aplikasi herbisida campuran glifosat + metil metsulfuron lebih efektif dibanding aplikasi glifosat tunggal dan tidak berpengaruh negatif terhadap tanaman karet. 
Berdasarkan uraian di atas perlu dilakukan penelitian untuk mengkaji dinamika gulma dan pertumbuhan lilit batang karet muda akibat berbagai interval pengendalian dan aplikasi herbisida sistemik dan kontak berbahan aktif tunggal serta campuran. Hasil penelitian ini diharapkan dapat digunakan sebagai bahan pertimbangan dalam memilih metode pengendalian gulma yang efektif dan efisien serta menguntungkan pertumbuhan tanaman karet.

\section{BAHAN DAN METODE}

Penelitian ini dilaksanakan dari bulan Januari 2013 sampai bulan Juni 2014. Lokasi penelitian di perkebunan karet rakyat di Desa Kemang Kecamatan Rantau Bayur, Banyuasin, Sumatera Selatan. Bahan-bahan yang digunakan dalam penelitian ini adalah; 1) tanaman karet klon PB 260, ditanam bulan November 2012, 2) herbisida kontak (parakuat diklorida) dan 3) herbisida sistemik (glifosat) dan herbisida sistemik metil metsulfuron. Alat yang digunakan sebagai berikut; 1) sprayer kapasitas 15 liter (merek solo), 2) gelas ukur, 3) ember dan 4) parang, 5) petak kuadrat dari besi $1 \mathrm{~m} \times 1 \mathrm{~m}$, 6) alat pengeringan gulma (oven), 7) timbangan analitik.

Penelitian ini dilakukan dengan rancangan Split Plot dengan tiga ulangan. Perlakuan interval waktu pengendalian gulma sebagai petak utama terdiri tiga taraf perlakuan $(\mathrm{A} 1=$ satu bulan sekali, A2 = tiga bulan sekali dan A3 = enam bulan sekali). Sedangkan anak petak adalah perlakuan aplikasi herbisida dengan enam taraf perlakuan yaitu: $\mathrm{B} 1=$ Herbisida Glifosat (dosis $7 \mathrm{~mL} / \mathrm{L}$ air atau $105 \mathrm{~mL} / \mathrm{sapel}), \mathrm{B} 2=$ Herbisida Parakuat diklorida (dosis $7 \mathrm{~mL} / \mathrm{L}$ air atau $105 \mathrm{~mL} / \mathrm{sapel}), \mathrm{B} 3=$ Herbisida Glifosat (dosis $7 \mathrm{~mL} / \mathrm{L}$ air) + Metil metsulfuron (dosis 0,266 g/L air atau 4,0 g/sapel), B4 = Herbisida Parakuat diklorida (dosis $7 \mathrm{~mL} / \mathrm{L}$ air) + Metil metsulfuron (dosis 0,266 g/L air atau 4,0 g/sapel ), B5 = cara manual, gulma dibersihkan dengan cara ditebas dan B6 = perlakuan kontrol, gulma tidak dikendalikan selama penelitian.

Aplikasi herbisida pada awal penelitian dilakukan serentak pada semua petak perlakukan menggunakan sprayer.
Waktu aplikasi herbisida selanjutnya diberikan sesuai dengan perlakuan. Pengamatan gulma yang tumbuh dilakukan dengan menggunakan patak kuadrat $1 \mathrm{~m} \mathrm{x} 1$ $m$ yang diamati pada awal penelitian (pra perlakuan) dan pasca perlakuan yaitu pada bulan Juni 2013, Desember 2013 dan Juni 2014. Pengamatan yang dilakukan terhadap gulma meliputi identifikasi gulma, menghitung jumlah gulma individu dan spesies gulma, mengestimasi penutupan gulma pada petak contoh dan bobot kering gulma, dilakukan dengan membongkar setiap jenis gulma yang tumbuh pada petak contoh. Gulma dikeringkan dalam oven pada suhu $100^{\circ} \mathrm{C}$ selama 48 jam, kemudian gulma ditimbang. Analisa vegetasi gulma dilakukan dengan metode kuadrat, variabel yang diukur adalah nilai Summed Dominance Ratio (SDR) spesies, komposisi, dan jenis gulma. Data bobot kering dan penutupan gulma dilakukan analisis dan uji lanjut Beda Nyata Terkecil (BNT) pada taraf 5\% (Gomez \& Gomez, 1995 ; Steel \& Torrie, 1995).

Pengamatan terhadap lilit batang karet diukur $5 \mathrm{~cm}$ dari pertautan okulasi, dilakukan pada awal penelitian (umur tanaman karet 2 bulan) dan pengamatan berikutnya dilakukan 6 bulan sekali. Data hasil pengamatan terhadap pertumbuhan lilit batang tanaman karet dilakukan analisis dan uji lanjut BNT pada taraf 5 persen dan analisis regresi hubungan antara bobot kering gulma dengan lilit batang tanaman karet. (Gomez \& Gomez, 1995 ; Steel \& Torrie, 1995).

\section{HASIL DAN PEMBAHASAN}

\section{Kondisi Pertumbuhan Gulma Pada Awal Penelitian}

Kondisi pertumbuhan gulma pada awal penelitian sebelum diberi perlakuan (Desember 2012) tersebar merata pada jalur dan gawangan tanaman karet. Hasil perhitungan nilai SDR gulma pada awal penelitian sebelum diberi perlakuan disajikan pada Tabel 1. Sebagian besar jenis gulma berasal dari spesies gulma daun lebar 26 spesies dan 12 spesies gulma daun sempit (rumput dan teki). Pertumbuhan gulma daun lebar lebih dominan (SDR $52,76 \%$ ) dibanding gulma daun sempit (SDR 
Tabel 1. Nilai SDR gulma pada awal penelitian sebelum perlakuan di kebun karet TBM Table 1. Weed SDR Value on Pre Treatment at Immature Rubber Plantation (IRP)

\begin{tabular}{|c|c|c|}
\hline No & $\begin{array}{l}\text { Nama gulma } \\
\text { Weed name }\end{array}$ & $\begin{array}{c}\text { Nilai SDR } \\
\text { SDR Value } \\
(\%)\end{array}$ \\
\hline & Daun sempit & \\
\hline 1. & Digitaria adscendets (H.B.K.) Hern & 19,55 \\
\hline 2. & Scleria sumatrensis & 8,31 \\
\hline 3. & Ischaemum timorense Kunth & 7,08 \\
\hline 4. & Axonopus compressus (Swartz.) & 4,32 \\
\hline 5. & Panicum repens & 2,53 \\
\hline 6. & Paspalum conjugatum Berg. & 2,13 \\
\hline 7. & Panicum maximum Jaeg. & 1,65 \\
\hline \multirow[t]{4}{*}{8.} & Scleria bancana & 0,52 \\
\hline & SDR no. 9-12 & 1,15 \\
\hline & SDR daun sempit & 47,24 \\
\hline & $\underline{\text { Daun lebar }}$ & 15,16 \\
\hline 1. & Merremia umbellata & 14,93 \\
\hline 2. & Borreria latifolia & 4,28 \\
\hline 3. & Clibadium arboreum & 2,52 \\
\hline 4. & Borreria laevis & 2,35 \\
\hline 5. & Ipomea triloba & 2,04 \\
\hline 6. & Eurphobia hirta & 1,86 \\
\hline 7. & Sida rombhifolia & 1,26 \\
\hline 8. & Urena labota & 0,93 \\
\hline 9. & Mimosa invisa & 0,86 \\
\hline 10. & Tetracera scandens (Linn.) Merr. & 0,64 \\
\hline 11. & Asystasia coromandeliana & 0,58 \\
\hline 12. & Ageratum coneyzoides & 0,52 \\
\hline 13. & Tetracera scandens (Linn.) Merr. & 0,48 \\
\hline 14. & Melastoma affinne (Linn.) & 0,45 \\
\hline 15. & Sparganophorus vaillantii Cranz. & 0,32 \\
\hline \multirow[t]{4}{*}{16.} & Stachytarpheta indica (Linn.) Vahl & 0,3 \\
\hline & SDR no. $17-26$ & 3,28 \\
\hline & SDR daun lebar & 52,76 \\
\hline & Jumlah SDR & 100 \\
\hline
\end{tabular}

47,24\%). Spesies yang memiliki nilai SDR tertinggi adalah Digitaria adscendets (H.B.K.) Hern $(19,55 \%)$, diikuti Merremia umbellata $(15,16 \%)$ dan Borreria latifolia $(14,93 \%)$. Pada kebun karet TBM awal penanaman, kondisi kebun masih cukup terbuka dan sebagian besar faktor pertumbuhan belum dimanfaatkan tanaman pokok (karet) sehingga ruang kosong yang ada di jalur dan gawangan biasanya akan segera ditumbuhi berbagai jenis gulma. Menurut Budi et al. (2008) pada lahan baru dibuka akan ditumbuhi dari jenis gulma herba dan rumput semusim, seperti Borreria latifolia, Ageratum coneyzoides, Mimosa invisa dan Digitaria adscendets (H.B.K.) Hern.

Pada kebun karet TBM diawal penelitian lebih banyak ditumbuhi jenis gulma semusim daun lebar dan sempit yang memiliki karakteristik reproduksi bijinya 
banyak dalam waktu singkat dan tumbuh pesat pada musim hujan. Dari aspek jumlah spesies jenis gulma daun lebar jauh lebih banyak tetapi dari Nilai SDR kedua jenis gulma tersebut hampir berimbang. Hal ini menunjukkan laju pertumbuhan dan perkembangan gulma daun sempit lebih cepat. Diduga penyebab spesies gulma dari daun lebar muncul sebagai gulma lebih dominan dari jenis gulma daun sempit pada awal penelitian dikarenakan jumlah spesiesnya jauh lebih besar.

\section{Pengaruh Perlakuan Terhadap Bobot Kering dan Penutupan Gulma}

Hasil pengamatan terhadap bobot kering dan penutupan gulma sebagai parameter pertumbuhan pada awal penelitian pra perlakuan kondisi pertumbuhan gulma relatif seragam dan masih berjalan lambat. Bobot kering dan penutupan gulma antar petak perlakuan pra perlakuan adalah $167,26-190,84 \mathrm{~g} / \mathrm{m}^{2}$ dan 56,50-64,62\% / $/ \mathrm{m}^{2}$. Hasil uji BNT terhadap bobot kering dan penutupan gulma antar petak perlakuan pada awal penelitian (pra perlakuan perlakuan) berbeda tidak nyata (Tabel 2, 3, 4 dan 5). Hal ini dikarenakan kondisi gulma pra perlakuan masih pada fase awal pertumbuhan karena pembukaan lahan dilakukan pada bulan Agustus dan awal musim hujan dimulai bulan Oktober. Pertumbuhan fase awal tumbuhan secara umum biasanya berjalan lambat dan akan meningkat sejalan dengan pertambahan waktu. Kondisi pertumbuhan gulma yang masih berjalan lambat sehingga bobot kering dan penutupan gulma yang dihasilkan antar petak perlakuan di awal penelitian relatif sama atau berbeda tidak nyata. Menurut Moenandir (2010) pertumbuhan gulma biasanya diasumsikan perubahan ukuran atau bobot berubah secara sigmoid atau eksponensial berdasarkan waktu.

Pengaruh perlakuan interval waktu pengendalian terhadap pertumbuhan gulma menunjukkan pertumbuhaan gulma makin tertekan pada petak perlakuan interval waktu pengendalian lebih singkat, yang dicerminkan bobot kering dan penutupan gulma yang dihasilkan setiap bulan. Hasil uji BNT pengaruh interval pengendalian terhadap bobot kering gulma yang dihasilkan antar petak perlakuan interval pengendalian satu, tiga dan enam bulan sekali berbeda nyata (Juni dan Desember 2013). Sedangkan pada bulan Juni 2014 hanya berbeda nyata antar perlakuan interval pengendalian enam bulan sekali dengan satu bulan sekali sedangkan terhadap perlakuan tiga bulan sekali berbeda tidak nyata (Tabel 2). Pengaruh perlakuan interval pengendalian terhadap penutupan gulma diketahui bahwa pentupan gulma berbeda nyata antara perlakuan interval pengendalian satu bulan sekali dengan dengan perlakuan tiga dan enam bulan sekali (Juni dan Desember 2013). Sedangkan pada bulan Juni 2014 punutupan gulma antar petak perlakuan interval pengendalian satu bulan sekali

Tabel 2. Pengaruh interval pengendalian pada bobot kering gulma di kebun karet TBM

Table 2. Effect of weed control interval on the dry weight of weed at immature rubber plantation

\begin{tabular}{ccccc}
\hline & \multicolumn{4}{c}{$\begin{array}{c}\text { Bobot kering gulma berbagai bulan } \\
\text { Dry weight of weed on each month } \\
\left(\mathrm{g} / \mathrm{m}^{2}\right)\end{array}$} \\
\cline { 2 - 5 } $\begin{array}{c}\text { Interval } \\
\text { pengendalian } \\
\text { Control interval }\end{array}$ & Pra & \multicolumn{3}{c}{$\begin{array}{c}\text { Pasca perlakuan } \\
\text { Post treatment }\end{array}$} \\
\cline { 2 - 5 } & Des 2012 & Juni 2013 & Des 2013 & Juni 2014 \\
& Dec 2012 & June 2013 & Dec 2013 & June 2014 \\
\hline A1 (satu bulan) & 172,60 & $709,18 \mathrm{a}$ & $1031,32 \mathrm{a}$ & $534,92 \mathrm{a}$ \\
A2 (tiga bulan) & 171,10 & $1427,8 \mathrm{~b}$ & $2849,45 \mathrm{~b}$ & $2181,83 \mathrm{~b}$ \\
A3 (enam bulan) & 192,99 & $1825,00 \mathrm{c}$ & $4110,18 \mathrm{c}$ & $3165,184 \mathrm{~b}$ \\
BNT 0,05 & 24,64 & 308,89 & 2521,43 & 1164,86 \\
\hline
\end{tabular}

Angka-angka yang diikuti oleh huruf yang sama pada kolom yang sama berarti tidak berbeda nyata

(Number followed by the same letter in the same column are not significantly different) 
dengan tiga bulan sekali berbeda tidak nyata (Tabel 3).

Pengaruh perlakuan aplikasi herbisida terhadap bobot kering dan pentupan gulma sebagai parameter pertumbuhan, menunjukkan bahwa secara umum pertumbuhan gulma lebih terhambat antara perlakuan herbisida dengan cara ditebas, antara perlakuan herbisida tunggal (glifosat) dengan parakuat dan antara herbisida campuran glifosat + metil metsulfuron dengan parakuat + metil metsulfuron. Pengaruh perlakuan aplikasi herbisida terhadap bobot kering gulma pada masing-masing petak perlakuan tertera pada Tabel 4. Dari data pada Tabel 4 diketahui bahwa bobot kering gulma lebih rendah pada perlakuan herbisida campuran glifosat + metil metsulfuron, diikuti perlakuan herbisida glifosat, parakuat dan parakuat + metil metsulfuron dan ditebas. Hasil uji BNT menunjukkan terhadap bobot kering gulma yang dihasilkan pada perlakuan glifosat + metil metsulfuron dengan perlakuan ditebas dan kontrol berbeda nyata sedangkan terhadap perlakuan lainnya berbeda tidak nyata (Juni 2013). Bobot kering gulma yang dihasilkan (Desember 2013) pada perlakuan glifosat +

Tabel 3. Pengaruh interval waktu pengendalian gulma terhadap penutupan gulma di kebun karet TBM

Table 3. Effect of weed control interval on the cover of weed at immature rubber plantation

\begin{tabular}{|c|c|c|c|c|}
\hline \multirow{3}{*}{$\begin{array}{l}\text { Interval } \\
\text { pengendalian } \\
\text { Control interval }\end{array}$} & \multicolumn{4}{|c|}{$\begin{array}{c}\text { Penutupan gulma berbagai bulan } \\
\text { Cover of weed on each month } \\
\left(\% \text { per } \mathrm{m}^{2}\right)\end{array}$} \\
\hline & Des 2012 & Juni 2013 & Des 2013 & Juni 2014 \\
\hline & Dec 2012 & June 2013 & Dec 2013 & June 2014 \\
\hline A1 (satu bulan) & $62,88(7,93)$ & $12,17(3,56) \mathrm{a}$ & $14,32(3,85) \mathrm{a}$ & $20,38(4,57) a$ \\
\hline A2 (tiga bulan) & $60,02(7,78)$ & $21,06(4,59) \mathrm{b}$ & $49,76(7,09) \mathrm{b}$ & $24,90(5,04) a$ \\
\hline A3 (enam bulan) & $60,65(7,82)$ & $21,40(4,68) b$ & $67,06(8,22) \mathrm{c}$ & $70,22(8,4) b$ \\
\hline BNT $0,05=$ & 0,42 & 0,49 & 0,37 & 0,72 \\
\hline
\end{tabular}

Nilai yang ada dalam kurung ( ) merupakan hasil tranformasi $(\sqrt{ } x+0,5)$

Angka-angka yang diikuti oleh huruf yang sama pada kolom yang sama berarti tidak berbeda nyata

(Number followed by the same letter in the same column are not significantly different)

Tabel 4. Pengaruh aplikasi herbisida terhadap bobot kering gulma di kebun karet TBM Table 4. Effect of herbicide application on the dry wieght of weed at IRP

\begin{tabular}{|c|c|c|c|c|}
\hline \multirow{4}{*}{$\begin{array}{l}\text { Aplikasi } \\
\text { herbisida } \\
\text { Herbicied } \\
\text { aplication }\end{array}$} & \multicolumn{4}{|c|}{$\begin{array}{l}\text { Bobot kering gulma setiap bulan } \\
\text { Dry weight of weed on each month } \\
\qquad\left(\mathrm{g} / \mathrm{m}^{2}\right)\end{array}$} \\
\hline & $\begin{array}{l}\text { Pra perlakuan } \\
\text { Pre treatment }\end{array}$ & & $\begin{array}{l}\text { asca perlakua } \\
\text { Post treatmen }\end{array}$ & \\
\hline & Des 2012 & Juni 2013 & Des 2013 & Juni 2013 \\
\hline & Dec 2012 & June 2013 & Dec 2013 & June 2013 \\
\hline B1 (gli) & 167,26 & $894,60 \mathrm{a}$ & $1244,17 \mathrm{ab}$ & $934,63 \mathrm{ab}$ \\
\hline B2 (par) & 170,15 & $1025,40 \mathrm{a}$ & $1769,38 \mathrm{bc}$ & $859,74 \mathrm{ab}$ \\
\hline $\mathrm{B} 3(\mathrm{gli}+\mathrm{mm})$ & 165,98 & $818,10 \mathrm{a}$ & 897,70 a & 596,81 a \\
\hline B4(par+ mm) & 170,83 & $967,80 \mathrm{a}$ & $1884,79 \mathrm{bc}$ & $1269,71 \mathrm{a}$ \\
\hline B5 (ditebas) & 189,31 & $1632,20 \mathrm{~b}$ & $3241,66 \mathrm{~d}$ & $1735,89 \mathrm{~b}$ \\
\hline B6 (kontrol) & 190,84 & $2587,8 \mathrm{c}$ & 8380,90 e & $4975,39 \mathrm{c}$ \\
\hline BNT 0,05 & 34,85 & 436,82 & 682,65 & 1165,45 \\
\hline
\end{tabular}

Angka-angka yang diikuti oleh huruf yang sama pada kolom yang sama berarti berbeda tidak nyata (Number followed by the same letter in the same column are not significantly different) 
metil metsulfuron berbeda nyata terhadap perlakuan lainnya kecuali dengan perlakuan glifosat. Sedangkan pada bulan Juni 2014, bobot kering gulma yang dihasilkan perlakuan glifosat + metil metsulfuron hanya berbeda nyata dengan perlakuan ditebas dan kontrol sedangkan terhadap perlakuan lainnya berbeda tidak nyata.

Pengaruh perlakuan aplikasi herbisida terhadap penutupan gulma selama penelitian memperlihatkan bahwa penutupan gulma lebih rendah pada perlakuan glifosat + metil metsulfuron, diikuti perlakuan glifosat sedangkan penutupan gulma lebih tinggi pada perlakuan ditebas dan kontrol. Penutupan gulma pada perlakuan herbisida campuran glifosat + metil metsulfuron selalu berbeda nyata terhadap perlakuan lainnya selama penelitian (Tabel 5). Pertumbuhan gulma lebih terhambat pada petak perlakuan pengendalian dengan herbisida dibanding pengendalian gulma dengan cara ditebas, karena herbisida dapat membunuh seluruh organ gulma yang terkena semprotan termasuk akar. Sedangkan pengendalian dengan cara ditebas hanya membunuh bagian organ yang terpotong dan bagian gulma yang tidak terpotong dalam waktu singkat akan membentuk tunas baru. Penebasan gulma hanya efektif untuk gulma perdu setahun dan kurang efektif untuk gulma tahunan serta untuk gulma rumput (Syawal \& Yakup, 2002). Penjelasan tersebut sebagai alasan yang menyebabkan bobot kering gulma di petak perlakuan herbisida lebih rendah dibanding pada petak perlakuan ditebas.

Bobot kering dan penutupan gulma lebih rendah pada petak perlakuan herbisida sistemik (glifosat) lebih rendah dibanding pada petak perlakuan herbisida kontak (parakuat). Hal ini disebabkan perbedaan daya berantas dan durasi pengendalian dari kedua jenis herbisida tersebut. Herbisida glifosat merusak atau membunuh organ di atas tanah dan dalam tanah sedangkan herbisida kontak tidak bisa mengendalikan organ di bawah tanah seperti akar dan rizoma gulma. Selanjutnya Adnan, Hasanuddin, \& Manfarizah (2012) menyatakan bahwa herbisida parakuat durasi efektif pengendalian lebih pendek (4,0 $-11,75$ minggu) dibandingkan dengan herbisida glifosat (14,5 -15,00 minggu). Konsekuensi durasi efektif pengendalian yang pendek menyebabkan dalam waktu lebih singkat pertumbuhan gulma lebih cepat.

Perlakuan herbisida campuran glifosat + metil metsulfuron lebih efektif menekan pertumbuhan gulma dibanding dengan perlakuan lainnya. Hal ini

Tabel 5. Pengaruh aplikiasi herbisida terhadap penutupan gulma di kebun karet TBM Table 5. Treatment effect of herbicide application on the cover of weed at IRP

\begin{tabular}{|c|c|c|c|c|}
\hline \multirow{4}{*}{$\begin{array}{l}\text { Aplikasi } \\
\text { herbisida } \\
\text { Herbicide } \\
\text { application }\end{array}$} & \multicolumn{4}{|c|}{$\begin{array}{c}\text { Penutupan gulma bebagai bulan } \\
\text { Cover of weed on each month } \\
\left(\% \text { per } \mathrm{m}^{2}\right)\end{array}$} \\
\hline & $\begin{array}{c}\text { Pra perlakuan } \\
\text { Pre treatment }\end{array}$ & \multicolumn{3}{|c|}{$\begin{array}{c}\text { Pasca perlakuan } \\
\text { Post treatment }\end{array}$} \\
\hline & Des 2012 & Juni 2013 & Des 2013 & Juni 2013 \\
\hline & Dec 2012 & June 2013 & Dec 2013 & June 2013 \\
\hline B1 (gli) & $64,62(8,07) a$ & $4,88(2,32) b$ & $26,54(5,20) b$ & $19,75(4,50) b$ \\
\hline B2 (par) & $56,50(7,55) a$ & $9,61(3,18) c$ & $31,08(5,62) b$ & $26,74(5,22) \mathrm{bc}$ \\
\hline $\mathrm{B} 3(\mathrm{gli}+\mathrm{mm})$ & $58,32(7,67) a$ & $1,72(1,49) a$ & $20,93(4,63) \mathrm{a}$ & $10,72(3,35) a$ \\
\hline $\mathrm{B} 4(\mathrm{par}+\mathrm{mm})$ & $59,64(7,75) \mathrm{a}$ & $7,62(2,85) b c$ & $26,74(5,22) b$ & $32,10(5,71) \mathrm{c}$ \\
\hline B5 (ditebas) & $63,66(8,01) a$ & $40,33(6,39) d$ & $59,25(7,73) \mathrm{c}$ & $51,92(7,24) \mathrm{d}$ \\
\hline B6 (kontrol) & $62,01(7,90) a$ & $87,86(9,43) \mathrm{e}$ & $98,10(9,93) \mathrm{d}$ & $99,99(10,02) e$ \\
\hline BNT 0,05 & 0,59 & 0,69 & 0,53 & 1,02 \\
\hline
\end{tabular}

Nilai yang ada dalam kurung ( ) merupakan hasil tranformasi $(\sqrt{ } x+0,5)$

Angka-angka yang diikuti oleh huruf yang sama pada kolom yang sama berarti berbeda tidak nyata

(Number followed by the same letter in the same column are not significantly different) 
dicerminkan dari bobot kering dan pentupan gulma yang dihasilkan lebih rendah dibandingkan dengan petak perlakuan herbisida lainnya. Pertumbuhan gulma lebih terhambat pada perlakuan herbisida campuran glifosat + metil metsulfuron karena perlakuan tersebut memperluas spektrum kerja herbisida yakni menghasilkan daya berantas yang lebih baik terhadap gulma berdaun sempit dan berdaun lebar. Hal lainnya adalah tingkat efektivitas pengendalian ditentukan durasi pengendalian, adanya pencampuran dengan bahan aktif sistemik (metil metsulfuron) akan meningkatkan durasi pengendalian lebih lama. Hasil penelitian ini sejalan dengan hasil penelitian Sinuraya dan Simanjuntak (2004) yang melaporkan pada perlakuan herbisida glifosat tunggal bobot kering gulma adalah $4,03 \mathrm{~g} / \mathrm{m}^{2}$ sedangkan pada perlakuan glifosat + metil metsulfuron, bobot kering gulma yaitu $3,87 \mathrm{~g} / \mathrm{m}^{2}$.

\section{Pengaruh Perlakuan Terhadap Pertumbuhan Lilit Batang Tanaman Karet}

Keragaman pertumbuhan lilit batang tanaman karet mulai terlihat antar interval pelakuan pada umur 14 bulan. Pertumbuhan lilit batang tanaman karet makin tertekan pada interval pengendalian lebih lama. Hasil uji BNT pengaruh perlakuan terhadap lilit batang karet menunjukan berbeda tidak nyata antara perlakuan interval pengendalian setiap bulan dengan perlakuan interval pengendalian tiga bulan sekali. Berbeda nyata antara perlakuan interval pengendalian setiap bulan dan tiga bulan sekali terhadap perlakuan interval pengendalian enam bulan sekali (Tabel 6).

Pada perlakuan interval pengendalian lebih singkat (setiap bulan) yang dilakukan secara terus menerus dapat menekan pertumbuhan gulma dan lama kelamaan jenis gulma yang peka akan mati. Berbeda pada perlakuan interval lebih lama (enam bulan sekali) gulma sempat untuk tumbuh dan berkembang di kebun karet. Menurut Syawal dan Yakup (2002) kehadiran gulma akan menguras sumber daya yang ada dengan cepat, jika berlangsung dalam waktu yang lama ketersediaan faktor pertumbuhan makin berkurang sehingga akan terjadi kompetisi dalam penggunaan faktor pertumbuhan tersebut. Tanaman karet merupakan tanaman yang memiliki tipe pertumbuhan ritme, yang proses pertumbuhannya segera terganggu jika faktor pertumbuhan terbatas. Jika berlangsung dalam waktu lama maka pertumbuhan akan terhenti secara temporer atau permanen (AidiDaslin, 2014). Pertumbuhan lilit batang karet ditentukan oleh proses pertumbuhan sekunder atau pertumbuhan ke samping pada batang yang sangat dipengaruhi ketersedian faktor pertumbuhan (Cambell et al., 2012). Diduga faktor pertumbuhan cukup tersedia pada petak perlakuan interval pengendalian 1-3 bulan sekali dan kurang tersedia pada petak perlakuan interval pengendalian 6 bulan sekali. Hal ini yang menyebabkan pertumbuhan lilit batang pada karet lebih tinggi pada petak perlakuan interval pengendalian lebih singkat.

Tabel 6. Pengaruh interval waktu pengendalian gulma terhadap pertumbuhan lilit batang tanaman karet

Table 6. The effect of weed control interval on the girth of rubber plant

\begin{tabular}{ccccc}
\hline \multirow{2}{*}{$\begin{array}{c}\text { Interval } \\
\text { pengedalian }\end{array}$} & \multicolumn{5}{c}{$\begin{array}{c}\text { Lilit batang pada berbagai umur } \\
\text { The girth on each age } \\
\text { Control interval }\end{array}$} & \multicolumn{4}{c}{\begin{tabular}{c} 
(cm) \\
\cline { 2 - 5 }
\end{tabular}} & $\begin{array}{c}8 \text { bulan } \\
(8 \text { month) }\end{array}$ & $\begin{array}{c}14 \text { bulan } \\
(14 \text { month) }\end{array}$ & $\begin{array}{c}\text { 20 bulan } \\
(20 \text { month })\end{array}$ \\
\hline A1 (satu bulan) & 2,03 & 4,86 & $10,37 \mathrm{~b}$ & $15,72 \mathrm{~b}$ \\
A2 (tiga bulan) & 2,22 & 4,88 & $9,73 \mathrm{~b}$ & $14,61 \mathrm{~b}$ \\
A3 (enam bulan) & 2,04 & 4,95 & $8,94 \mathrm{a}$ & $13,15 \mathrm{a}$ \\
\hline BNT 0,05= & tn & tn & 0,70 & 1,13 \\
\hline
\end{tabular}

Angka-angka yang diikuti oleh huruf yang sama pada kolom yang sama berarti berbeda tidak nyata (Number followed by the same letter in the same column are not significantly different) 
Dari data pada Tabel 7 memperlihatkan pertumbuhan lilit batang karet lebih tertekan pada perlakuan ditebas dibanding dengan perlakuan herbisida. Perlakuan herbisida berbahan aktif campuran memberikan pengaruh terhadap pertumbuhan tanaman karet lebih baik dibanding dengan perlakuan herbisida tunggal. Hasil uji BNT terhadap lilit batang karet pada umur karet 8 bulan, menunjukkan perlakuan parakuat + metil metsulfuron berbeda sangat nyata dengan perlakuan parakuat, ditebas dan kontrol, tetapi berbeda tidak nyata dengan perlakuan glifosat dan perlakuan parakuat + metil metsulfuron Perlakuan parakuat + metil metsulfuron berbeda tidak nyata dengan semua perlakuan lainnya terhadap lilit pada umur karet 14 bulan bulan. Perlakuan parakuat + metil metsulfuron berbeda sangat nyata dengan perlakuan ditebas dan kontrol, tetapi berbeda tidak nyata dengan perlakuan glifosat, parakuat, glifosat + metil metsulfuron terhadap lilit batang karet pada umur 20 bulan.

Perbedaan cara pengendalian gulma menyebabkan perbedaan spektrum dan durasi pengendalian terhadap gulma. Pengendalian dengan cara ditebas durasi pengendalian lebih singkat dibanding dengan herbisida. Hal ini akan menyebabkan dalam waktu 1,5-3 bulan akan segera terjadi persaingan gulma dengan tanaman jika gulma tidak dikendalikan (Budi et al., 2008). Kondisi tersebut menyebabkan derajat persaingan lebih tinggi dan berlangsung lebih lama pada petak perlakuan ditebas sehingga pertumbuhan lilit batang karet lebih terhambat.

Aplikasi hebisida campuran lebih efektif mengendalikan gulma karena terjadi peningkatan durasi dan daya berantas herbisida terhadap gulma. Diduga tingginya lilit batang karet pada petak perlakuan herbisida campuran karena faktor pertumbuhan lebih tersedia dan persaingan tidak terjadi atau jika terjadi derajatnya lebih rendah. Pernyataan ini sejalan dengan hasil penelitian Kuswanhadi (1990) yang melaporkan pertumbuhan lilit batang karet lebih baik pada perlakuan herbisida campuran glifosat + DMA sebesar 9,9 cm, herbisida tunggal glifosat sebesar 9,2 cm dan kontrol sebesar $8,9 \mathrm{~cm}$.

\section{Pengaruh Bobot Kering Gulma terhadap Pertambahan Lilit Batang Karet}

Hasil analisis regresi menunjukkan hubungan bobot kering gulma dengan lilit batang karet tertera pada Gambar 1. Dari Gambar 1 terlihat bahwa bobot kering gulma sangat mempengaruhi pertambahan lilit batang karet dengan bentuk (regresi) linier. Adapun persamaan hasil regresi untuk pertambahan lilit batang karet $\mathrm{Y}=-0,001 \mathrm{x}+$ 17,86 dengan nilai koefisien determinasi $\mathrm{R}^{2}$ $=0,82$. Hal ini menunjukkan bahwa pertumbuhan lilit batang karet $82,8 \%$

Tabel 7. Pengaruh aplikasi herbisida terhadap pertumbuhan lilit batang tanaman karet Table 7. The effect of herbicide application on the girth of rubber plant

\begin{tabular}{ccccc}
\hline \multirow{2}{*}{$\begin{array}{c}\text { Aplikasi } \\
\text { herbisida } \\
\text { Herbicede } \\
\text { application }\end{array}$} & $\begin{array}{c}\text { Lilit batang pada berbagai umur } \\
\text { The girth on each Age } \\
(\mathrm{cm})\end{array}$ \\
\cline { 2 - 5 } & 2 bulan & $\begin{array}{c}8 \text { bulan } \\
(8 \text { month })\end{array}$ & $\begin{array}{c}14 \text { bulan } \\
(14 \text { month })\end{array}$ & $\begin{array}{c}20 \text { bulan } \\
(20 \text { month })\end{array}$ \\
\hline $\mathrm{B}_{1}$ (gli) & 2,02 & $5,12^{\mathrm{c}}$ & $10,78^{\mathrm{cd}}$ & $16,26 \mathrm{~cd}$ \\
$\mathrm{~B}_{2}$ (par) & 2,05 & $5,07 \mathrm{c}$ & $10,30 \mathrm{c}$ & $15,54 \mathrm{c}$ \\
$\mathrm{B}_{3}$ (gli $\left.+\mathrm{mm}\right)$ & 2,35 & $5,34 \mathrm{~cd}$ & $11,44 \mathrm{~d}$ & $16,95 \mathrm{~cd}$ \\
$\mathrm{~B}_{4}$ (par+mm) & 2,10 & $5,51 \mathrm{~d}$ & $11,07 \mathrm{~cd}$ & $17,15 \mathrm{~d}$ \\
$\mathrm{~B}_{5}$ (ditebas) & 1,94 & $4,60 \mathrm{~b}$ & $8,41^{\mathrm{b}}$ & $12,65 \mathrm{~b}$ \\
$\mathrm{~B}_{6}$ (kontrol) & 2,10 & $3,74 \mathrm{a}$ & $6,05 \mathrm{a}$ & $8,41 \mathrm{a}$ \\
\hline BNT 0,05= & tn & 0,31 & 0,70 & 1,59 \\
\hline
\end{tabular}

Angka-angka yang diikuti oleh huruf yang sama pada kolom yang sama berarti berbeda tidak nyata (Number followed by the same letter in the same column are not significantly different) 


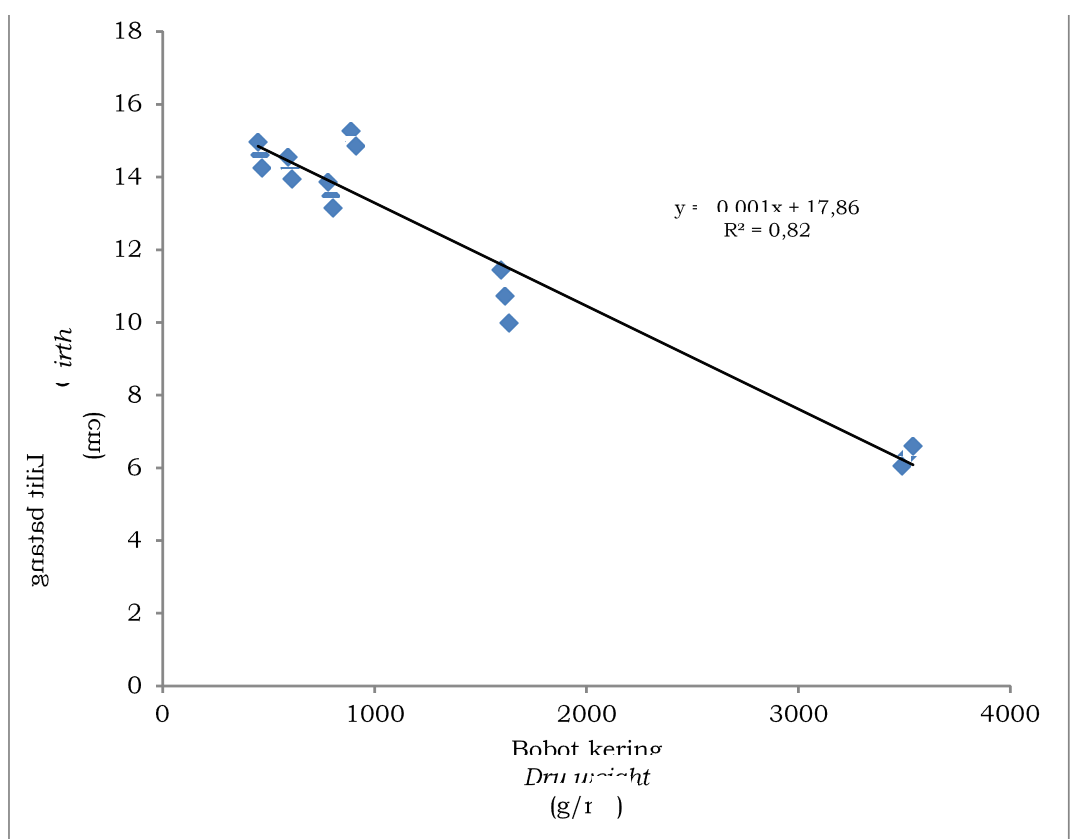

Gambar 1. Hubungan antara bobot kering gulma dengan lilit batang tanaman karet

Figure 1. Relationship between dry weight of weed to the girth of rubber plant

dipengaruhi faktor pertumbuhan (bobot kering) gulma dengan pola pertumbuhan membentuk hubungan yang negatif.

Ukuran lilit batang karet yang dihasilkan tanaman biasanya digunakan sebagai indikator optimum atau tidaknya kondisi faktor pertumbuhan yang ada. Menurut Nugroho, Istianto dan Karyudi (2012) jika lilit batang pada tanaman karet masa TBM, umur 20 bulan $>13,0 \mathrm{~cm}$ dapat dikategorikan normal dan $<13,0 \mathrm{~cm}$ pertumbuhan lilit batang sudah terhambat. Dari data pada Gambar 1 memperlihatkan bahwa pada petak perlakuan dengan bobot kering gulma $>1500 \mathrm{~g} / \mathrm{m}^{2}$, mengindikasikan faktor pertumbuhan sudah tidak optimum untuk mendukung pertumbuhan tanaman karet secara normal karena pertambahan lilit batang tanaman karet yang dihasilkan hanya $12,25 \mathrm{~cm}$. Ada kecenderungan dengan meningkat bobot kering gulma maka mengindikasikan semakin terbatas kondisi faktor pertumbuhan yang tersedia.

\section{KESIMPULAN}

Kesimpulan yang dapat ditarik dari hasil penelitian ini adalah bahwa pertumbuhan gulma daun lebar lebih dominan (nilai SDR 52,47\%) dibanding gulma daun sempit $(47,24 \%)$ pada awal penelitian di kebun karet TBM, pertumbuhan gulma lebih tertekan pada perlakuan interval pengendalian lebih singkat dan pada perlakuan glifosat + metil metsulfuron, bobot kering dan penutupan gulma selalu berbeda nyata antara perlakuan glifosat + metil metsulfuron dengan perlakuan ditebas dan kontrol, pertumbuhan lilit batang tanaman karet lebih baik pada perlakuan herbisida campuran; parakuat + metil metsulfuron $(17,1 \mathrm{~cm})$ diikuti pada perlakuan glifosat + metil metsulfuron $(16,9 \mathrm{~cm})$, pertumbuhan lilit batang karet hanya berbeda antara perlakuan parakuat + metil metsulfuron dengan perlakuan herbisida parakuat, ditebas dan kontrol sedangkan terhadap perlakuan lainnya berbeda tidak nyata dan pertumbuhan lilit batang karet sangat dipengaruhi bobot kering gulma $\left(\mathrm{R}^{2}=0,82\right)$ dengan pola pertumbuhan membentuk hubungan yang negatif $(\mathrm{Y}=-0,001 \mathrm{x}+$ $17,86)$.

\section{UCAPAN TERIMA KASIH}

Penulis mengucapkan terimakasih kepada Kepala Badan SDMP, Kepala Pusat 
Pendidikan Pertanian, Kepala SMK-PP Sembawa dan Staf atas bantuannya selama ini. Kepala dan Staf Laboratorium Kesuburan Tanah Fakultas Pertanian Universitas Sriwijaya atas fasilitas penelitian yang disediakan.

\section{DAFTAR PUSTAKA}

Adnan, M., Hasanuddin., \& Manfarizah. (2012). Aplikasi beberapa dosis herbisida glifosat dan parakuat pada sistem tanpa olah tanah serta pengaruhnya terhadap sifat kimia tanah, karakteristik gulma dan hasil kedelai. Jurnal Agrista, 6(3), 42-51.

Aidi-Daslin. (2014). Produktivitas klon karet IRR 100 dan 200 pada berbagai agroklimat dan sistem sadap. Warta Perkaretan, 3(1), 11-18.

Budi., Akiefnawati, R., Wibawa, G., Ilahang., \& Penot, E. (2008). Pengaruh penyiangan dan pemupukan terhadap pertumbuhan tanaman karet pada sistem RAS 1 di Kalimantan Barat. Jurnal Penelitian Karet, 26(2), 144152 .

Cambell, N. A., Reece, J. B., Urry, L. A., Cain, M. C., Wasserman, S.A., Minarsky, P. V., \& Jacson, R. B. (2012). Biologi Edisi Delapan Jilid 2 . Jakarta, Indonesia: Erlangga.

Damanik, S., Syakir, M., Tasma, M., \& Siswanto. (2010). Budidaya dan Pasca Panen Karet. Jakarta, Indonesia: Kementerian Pertanian.

Faisal, R., Siregar, E. B. M., \& Anna, N. (2013). Inventarisasi gulma pada tegakan tanaman muda Eucalyptus spp. Peronema Forestry Science Journal, 2(2), 44-49.

Faiz, M. A. A. (2006). Efficacy of glyfosate and its mixtures against weed under young rubber forest plantation. Journal Rubber Research Institut of Malaysia, 9(1), 50-60.
Fatonah, S., Asih, D., Mulyanti, D., \& Iriani, D. (2013). Penentuan waktu pembukaan stomata pada gulma melastoma malabathricum L. di perkebunan gambir, Kampar Riau. Biospecies, 6(2), 15-22.

Girsang, W. (2012). Pengaruh tingkat dosis herbisida isopropilamina glifosat dan selang waktu terjadinya pencucian setelah aplikasi terhadap efektifitas pengendalian gulma pada kebun karet (Hevea brasiliensis) TBM. Jurnal Penelitian Bidang Ilmu Pertanian, 3(2), 31-36.

Gomez, K. A., \& Gomez, A. A. (1995). Prosedur Statistik Untuk Penelitian Pertanian. Jakarta, Indonesia: Universitas Indonesia Press.

Isda, M. N., Fatonah, S., \& Fitri, R. (2013). Potensi ekstrak daun gulma babadotan (Ageratum conyzoides L.) terhadap perkecambahan dan pertumbuhan Paspalum conjugatum Berg. Al-Kauniyah Jurnal Biologi, 6(2), 120-125.

Krisno, M. A. (2016). Pembuatan herbisida organik di kelompok tani sumber urip1 Desa Wonorejo Kecamatan Poncokusumo Kabupaten Malang. Jurnal Dedikasi, 13, 75-82.

Kuswanhadi. (1990). Beberapa herbisida campuran untuk mengendalikan gulma pada jalur tanaman karet muda. Bulletin Lateks, 5(1), 24-28.

Moenandir, J. (2010). Ilmu Gulma. Malang, Indonesia: Universitas Brawijaya Press.

Nugroho, P. A., Istianto., \& Karyudi. (2007). Metode meningkatkan tanaman karet belum menghasilkan. Warta Perkaretan, 26(2), 10-19. 
Saleh, D. (2011). Mengantisipasi dampak krisis di Eropa dan USA terhadap industri dan perdagangan karet Indonesia. Makalah Seminar Nasional Bidang Perkebunan. (27 p.). Palembang, Indonesia: Universitas Sriwijaya.

Salisbury, F. B., \& Ross, C. W. (1995). Fisiologi Tumbuhan Jilid 3. Perkembangan Tumbuhan dan Fisiologi Lingkungan. Edisi Keempat. Bandung, Indonesia: ITB.

Sari, H. F. M., \& Rahayu, S. S. B. (2013). Jenis-jenis gulma yang ditemukan di perkebunan karet (Hevea brasiliensis) Desa Rimbo Datar Kabupaten 50 Kota Sumatera Barat. Biogenesis, 1(1), 2832.

Sembodo, D. R. J. (2010). Gulma dan Pengelolaannya. Yogyakarta, Indonesia: Graha Ilmu.

Sinuraya, G., \& Simanjuntak, K. (2004). Pengaruh aplikasi beberapa herbisida terhadap munculnya suksesi gulma pada tanaman karet. Prosiding Konferensi Nasional XVI. Himpunan Ilmu Gulma Indonesia (p. 173-183). Bogor, Indonesia: HIGI.

Steel, R. G. D., \& Torrie, J. H. (1995). Prinsip dan Prosedur Statistika Suatu Pendekatan Biometrik. Jakarta, Indonesia: PT Gramedia Pustaka Utama.

Supawan, I. G., \& Hariyadi. (2014). Efektivitas herbisida IPA Glifosat 486 SL untuk pengendalian gulma pada budidaya tanaman karet (Hevea brasiliensis Muell. Arg) belum menghasilkan. Bul. Agrohorti, 2(1), 95103.
Supriadi, M. (2011). Upaya peningkatan daya saing perkebunan karet melalui penerapan teknologi menuju usaha perkebunan yang berkelanjutan. Makalah Seminar Nasional Bidang Perkebunan (25 p.). Palembang, Indonesia: Universitas Sriwijaya.

Suryaningtyas, H., \& Kuswanhadi. (1994). Pengaruh sistem dan frekuensi penyiangan gulma terhadap pertumbuhan tanaman karet muda belum. Prosiding Konferensi XII Himpunan Ilmu Gulma Indonesia (p. 491-496). Padang, Indonesia:HIGI.

Suryaningtyas, H. (2014). Pengendalian Gulma Sapta Bina Usaha Karet Rakyat (p. 79-89). Palembang, Indonesia: Balai Penelitian Sembawa.

Syawal, Y., \& Yakup. (2002). Gulma dan Teknik Pengendaliannya. Edisi Revisi. Jakarta, Indonesia: PT. Raja Grafindo Persada.

Syarifah, A. P., Suhendry, I., \& Sayurandi. (2014). Genotipe terpilih berdasarkan karakteristik pertumbuhan dan hasil lateks dari UP/03/96. Jurnal Penelitian Karet, 32(1), 98-108.

Wibowo, A., \& Nazif, M. (2007). Efektivitas herbisida monoamonium glifosat untuk pengendalian gulma di bawah tegakan sengon di Parung Panjang Jawa Barat. Jurnal Penelitian Hutan Tanaman, 4(1), 37-50. 